\title{
Identification of a small HSP gene from hard clam Meretrix meretrix and its potential as an environmental stress biomarker
}

\author{
Hongjun $\mathrm{Li}^{1, *}$, Shuxi Liu ${ }^{1}$, Chongbo $\mathrm{He}^{2}$, Xianggang Gao ${ }^{2}$, Xiutang Yuan ${ }^{1}$ \\ ${ }^{1}$ Key Laboratory for Ecological Environment in Coastal Areas (SOA), National Marine Environmental Monitoring Center, \\ Dalian 116023, China \\ ${ }^{2}$ Key Laboratory of Marine Fishery Molecular Biology of Liaoning Province, \\ Liaoning Ocean and Fisheries Science Research Institute, Dalian 116023, China
}

\begin{abstract}
Heat shock proteins (HSPs) are molecular chaperones that help organisms cope with stressful conditions. In this study, a novel small HSP (sHSP) gene was identified from the hard clam Meretrix meretrix (designated as Mm-HSP20). The full length of the cDNA is $1222 \mathrm{bp}$, consisting of a 5'-terminal untranslated region (5'UTR) of $103 \mathrm{bp}$, a 3'UTR of $565 \mathrm{bp}$, and a $522 \mathrm{bp}$ open reading frame encoding a polypeptide of 173 amino acids. Sequence comparison showed that Mm-HSP20 had a moderate degree of homology to the sHSP of other organisms. A sHSP feature domain, an alpha-crystallin domain, and a V/IXI/V motif in the C-terminal extension were identified in the Mm-HSP20 amino acid sequence, indicating that Mm-HSP20 is a new member of the sHSP family. The Mm-HSP20 transcript was constitutively expressed in 6 different test tissues, with the highest expression level detected in the digestive gland by fluorescent quantitative realtime PCR. The temporal expression of Mm-HSP20 mRNA in the digestive gland and hemocytes was evaluated after exposure to cadmium $(\mathrm{Cd})\left(40 \mu \mathrm{g} \mathrm{l}^{-1} \mathrm{CdCl}_{2}\right)$ and benzo[a]pyrene $\left(50 \mu \mathrm{g} \mathrm{l}^{-1}\right.$ $\mathrm{B}[\mathrm{a}] \mathrm{P})$ individually, and in combination $\left(40 \mathrm{\mu g} \mathrm{l}^{-1} \mathrm{CdCl}_{2}+50 \mu \mathrm{g} \mathrm{l}^{-1} \mathrm{~B}[\mathrm{a}] \mathrm{P}\right)$. Mm-HSP20 expression level increased significantly after $\mathrm{Cd}$ and $\mathrm{B}[\mathrm{a}] \mathrm{P}$ exposure in both tissue types. Conversely, significant Mm-HSP20 transcript repression was detected in the $24 \mathrm{~h} \mathrm{~B}$ [a]P-treated digestive gland samples. Considerable up-regulation of Mm-HSP20 mRNA level was observed after multiple exposures. These results indicate that Mm-HSP20 plays a role in mechanisms involved in coping with environmental stress in hard clams. Mm-HSP20 may be suitable for use as a biomarker for heavy metal and $\mathrm{B}[\mathrm{a}] \mathrm{P}$ contamination.
\end{abstract}

KEY WORDS: Hard clam - Meretrix meretrix $\cdot$ HSP20 - mRNA expression · Heavy metal $\cdot$ Cd $\cdot$ Benzo[a]pyrene $\cdot$ Biomarker

Resale or republication not permitted without written consent of the publisher

\section{INTRODUCTION}

The continuous development and expansion of industry, coupled with increasing human activity, has caused marine environments to deteriorate rapidly (Rainbow 1995). With the profound economic growth in China, heavy metal pollution has become a serious concern in estuarine and coastal regions. Contamination levels have dramatically increased in recent years (Pan \& Wang 2012). The Bohai Sea is considered one of the most contaminated areas because of the high input of anthropogenic pollutants from adjacent terrestrial rivers. For example, in Jinzhou Bay on the northwestern coast of the Bohai Sea, the concentrations and burial fluxes of $\mathrm{Zn}, \mathrm{Pb}, \mathrm{Cd}$, and $\mathrm{Hg}$ have increased abruptly since the late 1970s (Xu et al. 2009). Heavy metals are pervasive in this region for several reasons: they arise from a wide variety of 
sources, they bioaccumulate, and they are not biodegradable (Zhang et al. 2006). Among these, cadmium $(\mathrm{Cd})$ is one of the most abundant and ubiquitously distributed toxic elements found in aquatic systems (Yuan et al. 2004, Wan et al. 2008). The concentrations of heavy metals observed in coastal sediments are several times higher than those in water columns, and they can have considerable adverse effects on marine organisms. The bioaccumulation of sediment-bound metals in benthic species is extremely important in food webs and ultimately to humans (Wang 2002).

Benzo[a]pyrene $(\mathrm{B}[\mathrm{a}] \mathrm{P})$ is a representative polycyclic aromatic hydrocarbon (PAH). It is therefore classified as a pervasive environmental contaminant. $\mathrm{B}[\mathrm{a}] \mathrm{P}$ is found in water columns and sediments (Men et al. 2009). It enters marine environments via anthropogenic sources, including petroleum spillage, industrial discharge, and urban runoff (Soclo et al. 2000, Boonyatumanond et al. 2006). B[a]P bioaccumulation causes damage to various organ systems in exposed aquatic organisms. Toxicological studies have demonstrated the effects of $\mathrm{B}[\mathrm{a}] \mathrm{P}$ on organisms at genotoxic, biochemical, and physiological levels (Lowe et al. 2006, Reynaud \& Deschaux 2006, Binelli et al. 2008, Banni et al. 2010).

Heat shock proteins (HSPs) are highly conserved ubiquitous chaperone proteins. HSPs have been classified into several families: HSP90 (85 to $90 \mathrm{kDa})$, HSP70 (68 to $73 \mathrm{kDa}$ ), HSP60, HSP47, and small HSPs (12 to $43 \mathrm{kDa}$ ), according to their molecular size (Morimoto 1993, Franck et al. 2004). The HSP family includes a number of members that help modulate organisms' stress responses and protect them from environmentally induced cellular damage (Lindquist \& Craig 1988, Parsell \& Lindquist 1993, Hartl 1996, Feder \& Hofmann 1999). Small HSPs (sHSPs) act as molecular chaperones. Under cellular stress conditions, they bind partially denatured proteins, preventing irreversible protein aggregation (Sun \& MacRae 2005). sHSP cDNA sequences have been isolated and characterized in bivalve species, such as the bay scallop Argopecten irradians, Zhikong scallop Chlamys farreri, Manila clam Ruditapes philippinarum, and bloody clam Tegillarca granosa (Li et al. 2010, Zhang et al. 2010a,b, Bao et al. 2011). HSP22 expression has been shown to have a close correlation to heavy metal exposure in the bay scallop and to respond to bacterial challenge in the Zhikong scallop (Zhang et al. 2010a,b). To date, most researchers have focused on characterization of sHSP function in single stress responses, but there are a few studies characterizing the toxic effects of complex pollution exposures. Wang et al. (2011) indicated that coexposure to $\mathrm{Cd}$ and $\mathrm{B}[\mathrm{a}] \mathrm{P}$ greatly enhanced bioaccumulation of these compounds in Ruditapes philippinarum, which suggested that accumulated $\mathrm{Cd}$ and $\mathrm{B}[\mathrm{a}] \mathrm{P}$ in clams apparently interact with each other and may, therefore, greatly modify the toxic effect of the individual chemicals.

Marine organisms from coastal waters experience environmental challenges that generate stressful conditions (Zhang et al. 2012). Bivalve mollusks are ideal for assessments of levels of environmental pollution in coastal and estuarine areas because they are ubiquitous, sedentary, and filter feeders (Boening 1999, Zhang et al. 2012). The hard clam Meretrix meretrix is a bivalve mollusk native to the eastern coastal area of Asia (Li et al. 2009). It is also a highpriced commercial commodity in the fishery trade. After generations of successful aquaculture, the clam industry in China has experienced serious losses from disease-induced mortality (Yue et al. 2010). It is suspected that deteriorating environmental quality is one of the primary causes of disease in aquaculture. Marine environment contamination levels can be assessed by their impact on endogenous organisms. Given its wide distribution and sedentary lifestyle, M. meretrix is ideal for identifying the toxicological effects of biologically available marine pollutants. Wang et al. $(2009,2010)$ reported M. meretrix larvae were highly sensitive to heavy metal contamination, and $\mathrm{Cd}$ exposure induced antioxidant enzymatic activities at the early development stage. The purpose of the present study was (1) to clone a novel HSP20 gene from hard clam (designated as MmHSP20), (2) to investigate the expression pattern of Mm-HSP20 in different tissues and its temporal response to single and combined pollutant exposures, and (3) to evaluate the potential of MmHSP20 as a biomarker of heavy metal and B[a]P contamination.

\section{MATERIALS AND METHODS}

\section{Clam collection}

Adult Meretrix meretrix (2 yr old, 4.5 to $5.5 \mathrm{~cm}$ shell length) were collected in September (out of the breeding season) from the experimental shellfish farm of Guanhe Aquaculture Corporation in Panjin (Bohai Sea, China). Clams were cultured in sandfiltered seawater at 18 to $20^{\circ} \mathrm{C}$ for $10 \mathrm{~d}$ before exposure experiments. The seawater was aerated continuously, and salinity was set at 32 . In order to 
maximize the natural filtering activity, the clams were kept in the tank-rearing conditions with clean seawater. The depuration process prevented any external environmental recontamination. Clams were fed Chlorella vulgaris (10 mg dry mass clam $^{-1} \mathrm{~d}^{-1}$ ) during the acclimatization period. To investigate the tissue-specific expression pattern of Mm-HSP20, 6 tissues including hemocytes, mantle, gill, adductor muscle, digestive gland, and gonad, from 5 unchallenged clams were collected. Hemolymph was collected from adductor muscles using a sterile syringe and then centrifuged at $1000 \times g$ for $10 \mathrm{~min}$ at $4^{\circ} \mathrm{C}$. All samples were stored in liquid nitrogen until RNA extraction.

\section{Pollutant exposure experiments}

All experiments were performed at $20^{\circ} \mathrm{C}$. Seawater salinity was maintained at 32 . For pollutant exposure experiments, clams were randomly divided into 12 flat-bottomed rectangular tanks, each with a 501 capacity. Each tank contained 30 clams. There were 4 experimental groups: (1) control, (2) $40 \mu \mathrm{g} \mathrm{l^{-1 }}$ $\mathrm{CdCl}_{2}$, (3) $50 \mathrm{\mu g} \mathrm{l}^{-1} \mathrm{~B}[\mathrm{a}] \mathrm{P}$, and (4) combined pollutants $\left(40 \mu \mathrm{g} \mathrm{l}^{-1} \mathrm{CdCl}_{2}+50 \mu \mathrm{g} \mathrm{l}^{-1} \mathrm{~B}[\mathrm{a}] \mathrm{P}\right)$. The pollutant concentrations were determined according to previous heavy metal and $\mathrm{B}[\mathrm{a}] \mathrm{P}$ contamination studies performed in the coastal waters and sediments of northern China (Meng et al. 2008, Hu et al. 2010). The $\mathrm{B}[\mathrm{a}] \mathrm{P}$ was first dissolved in dimethyl sulfoxide (DMSO) and then added to seawater for a final DMSO concentration of $0.0025 \%$. Clams were not fed during the exposure experiments. No clams died during the exposure phase of the experiment, indicating that these challenge concentrations were below lethal doses. The digestive gland and hemocytes of 4 clams from each treatment group were randomly sampled at $0,24,48$, and $96 \mathrm{~h}$ post-exposure. All samples were preserved in liquid nitrogen until RNA extraction.

\section{RNA extraction and cDNA synthesis for gene cloning}

Total RNA was extracted using Trizol reagent (Invitrogen) in accordance with the manufacturer's protocol. Total RNA was incubated with RNase-free DNase I (Roche) to remove any genomic DNA. Firststrand cDNA was synthesized from $2 \mu \mathrm{g}$ of total RNA by $\mathrm{M}-\mathrm{MLV}$ reverse transcriptase using oligo $\mathrm{d}(\mathrm{T})_{15}$ (Takara) at $37^{\circ} \mathrm{C}$ for $60 \mathrm{~min}$.

\section{Cloning and sequencing of the full-length cDNA of Mm-HSP20}

Random sequencing of SMART cDNA libraries generated 3224 successful sequencing reactions (Li et al. 2011). BLAST (NCBI) analysis of all obtained sequences revealed that an expressed sequence tag (EST) of $744 \mathrm{bp}$ was homologous to previously identified sHSPs. This EST sequence, Mm-HSP20, was selected for cloning and further investigation. One gene-specific primer Mm-HSP20-3' (Table 1) was designed to amplify the full-length cDNA of MmHSP20 using the rapid amplification of cDNA ends (RACE) approach. PCR amplification of the 3' end of Mm-HSP20 was carried out with Mm-HSP20-3' and T7 primers (Table 1). The PCR profile was set as follows: $94^{\circ} \mathrm{C}$ for $5 \mathrm{~min}$, followed by 35 cycles of $94^{\circ} \mathrm{C}$ for $30 \mathrm{~s}, 55^{\circ} \mathrm{C}$ for $30 \mathrm{~s}, 72^{\circ} \mathrm{C}$ for $1 \mathrm{~min}$, and an additional extension of $72^{\circ} \mathrm{C}$ for $10 \mathrm{~min}$. The PCR product was cloned into the pMD18-T vector (Takara) and sequenced in both directions.

\section{Sequence alignment and phylogenetic tree}

The Mm-HSP20 sequence was analyzed using the BLAST algorithm at the NCBI website (www.ncbi. nlm.nih.gov/blast). The amino acid sequence was predicted using the Expert Protein Analysis System (www.expasy.org/). The calculated molecular mass

Table 1. Primer sequences used in this study. HSP: heat shock protein; RACE: rapid amplification cDNA ends

\begin{tabular}{|lll|}
\hline Primer name & Primer sequence & Sequence information \\
\hline Mm-HSP20-3' & GATTGCTCTGATCTGTTATGAGAAG & 3' RACE primer \\
T7 & GTAATACGACTCACTATAGGGC & Vector primer \\
HSP20-RTF & GATGCTGGATCGTCTATGCTTC & Real-time HSP20 primer (forward \& reverse) \\
HSP20-RTR & TGGTTTTCACGCTAATTTCTTCC & \\
actin-RTF & GATCATTGCCCCACCAGAGAG & Real-time $\beta$-actin primer (forward \& reverse) \\
actin-RTR & CCAGACTCGTCGTATTCTTGTTTAC & \\
\hline
\end{tabular}


and theoretical isoelectric point were predicated by the EMBOSS model of protein isoelectric point program (http://isoelectric.ovh.org/). Multiple protein sequence alignments of Meretrix meretrix HSP20 with other species were performed using the ClustalW program (www.ebi.ac.uk/clustalw/). A phylogenetic tree was constructed according to the amino acid sequences of selected HSPs using the neighbor-joining (NJ) method in the program MEGA 4.0 (Tamura et al. 2007). The bootstrap trials were replicated 1000 times to derive confidence values for the phylogeny analysis.

\section{Analysis of Mm-HSP20 mRNA expression using quantitative real-time qRT-PCR}

The mRNA expression of Mm-HSP20 in different tissues of healthy clams was measured by qRT-PCR (quantitative real-time PCR). Gene-specific primers (forward and reverse) HSP20-RTF and HSP20-RTR (Table 1) were designed to amplify the target gene. A pair of primers for clam $\beta$-actin (actin-RTF and actin-RTR; Table 1 ) was used to amplify $\beta$-actin as an internal control. Reactions were performed in a total volume of $25 \mu \mathrm{l}: 12.5 \mu \mathrm{l} 2 \times$ SYBR Premix Ex Taq ${ }^{\mathrm{TM}}$, $0.5 \mu \mathrm{l}$ ROX II, $1.0 \mu \mathrm{l}$ each primer $\left(10 \mu \mathrm{mol} \mathrm{l^{-1 }}\right), 2.0 \mu \mathrm{l}$ diluted cDNA, and $8.0 \mu \mathrm{l}$ DEPC-water. The thermal profile was set as follows: $95^{\circ} \mathrm{C}$ for $30 \mathrm{~s}$, followed by 40 cycles of $95^{\circ} \mathrm{C}$ for $5 \mathrm{~s}$ and $60^{\circ} \mathrm{C}$ for $50 \mathrm{~s}$. Dissociation curve analysis was performed at the end of each reaction to confirm that only 1 PCR product was amplified and detected. The $2^{-\Delta \Delta \mathrm{Ct}}$ method (Livak \& Schmittgen 2001) was used to analyze expression levels. All data were given in terms of relative mRNA expressed as means $( \pm \mathrm{SD})$. The data were subjected to analysis by a 1-way ANOVA, using SPSS 13.0. A p-value $<0.05$ was considered statistically significant.

\section{RESULTS AND DISCUSSION}

\section{Characterization of the full-length cDNA of Mm-HSP20}

The complete Mm-HSP20 cDNA sequence (GenBank Accession No. JQ734546) is 1216 bp in length. It contains a 5' untranslated region (UTR) of $104 \mathrm{bp}$ and a 519 bp open reading frame (ORF) which encodes a 173 amino acid protein (Fig. 1) and a 3'UTR of $567 \mathrm{bp}$. The predicted molecular weight of the mature Mm-HSP20 was $20.4 \mathrm{kDa}$, and the theo- retical isoelectric point was 6.76. SMART analysis revealed that the predicted amino acid sequence of Mm-HSP20 contained an alpha-crystallin domain (ACD) of approximately 90 amino acids, which is a hallmark of the sHSP subfamily (Cheng et al. 2008) (Fig. 2). The ACD contains several $\beta$-strands organized into $2 \beta$-sheets responsible for dimer formation, the basic building block of most sHSPs (Sun \& MacRae 2005).

\section{Sequence alignment and phylogenetic analysis}

Multiple sequence alignments revealed that MmHSP20 shared a moderate level of similarity with other known sHSPs (Fig. 2). Specifically, it showed $56 \%$ similarity to the mussel Mytilus galloprovincialis, $55 \%$ to the clam Ruditapes philippinarum, $27 \%$ to the catfish Clarias batrachus, $25 \%$ to the honeybee Apis mellifera, $18 \%$ to the bay scallop (Argopecten irradians), and 16\% to the Zhikong scallop (Chlamys farreri). The sHSPs are some of the most structurally diverse known stress-response proteins (Narberhaus 2002). Their molecular size ranges from 12 to $43 \mathrm{kDa}$. This is due to the profound variations in length of their $\mathrm{N}$-terminal regions (Franck et al. 2004). Despite the relatively low overall sequence similarity found in this group, sHSPs do feature common ACD domains and IXI/V motifs in the C-terminal extension. The IXI/V motifs appear to be important in the temperature-dependent, chaperone-like activity of the ACDs (Pasta et al. 2004). These regions demonstrate considerable similarity across different species.

A phylogenic tree based on HSP protein sequences was constructed (Fig. 3). In the tree, sHSP, HSP70, and HSP90 clustered independently, forming 3 sister groups. Mm-HSP20 was segregated to the sHSP clade, confirming its membership in the sHSP subfamily. Considering the sHSP subclass, Mm-HSP20 was first clustered with sHSP1 from Ruditapes philippinarum, and then formed a sister subgroup with Mytilus galloprovincialis. Considering the low level of similarity between Mm-HSP20 and its scallop (Argopecten irradians and Chlamys farreri) counterparts, it was proposed that they belong to different subtypes of the sHSP family. Analysis of sHSP protein sequences from other species, such as insects, fish, and mammals clustered into their corresponding subgroups. Despite the low level of similarity between sHSP family members, topology approximately reflected the taxonomic status of the corresponding species in our study. 


\section{GGGGGACAGAGTACTTGCCGTAACGATAGGTAAAACACTAGAGCGCCATTGCATAGAAGT}

(1)

TAACATTATATAGATATAGTAAAATACGAGAAAATAAATAAAAATGTCTTGGAAAATAGT $\begin{array}{llllllllllllllllllll}P & L & F & K & R & D & F & G & F & F & D & R & Q & R & D & L & F & S & D & W\end{array}$ ACCGTTGTTTAAAAGGGACTTTGGATTTTTCGATCGTCAGAGAGATCTGTTTTCGGACTG $\begin{array}{llllllllllllllllllll}V & K & E & F & D & D & E & W & K & S & M & D & F & E & S & S & R & M & K & F\end{array}$ GGTGAAGGAATTCGACGATGAATGGAAATCTATGGACTTTGAATCTTCACGAATGAAGTT

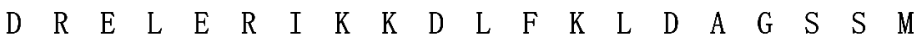
TGATAGAGAATTAGAAAGAATAAAGAAAGATCTTTTCAAGTTGGATGCTGGATCGTCTAT $\begin{array}{llllllllllllllllllll}\mathrm{L} & Q & \mathrm{~V} & \mathrm{E} & \mathrm{R} & \mathrm{P} & \mathrm{F} & \mathrm{V} & \mathrm{T} & \mathrm{D} & \mathrm{P} & \mathrm{A} & \mathrm{G} & \mathrm{N} & \mathrm{K} & \mathrm{K} & \mathrm{L} & \mathrm{A} & \mathrm{L} & \mathrm{R}\end{array}$ GCTTCAAGTTGAGAGGCCGTTTGTAACAGATCCTGCAGGAAACAAAAAGCTCGCTCTTCG $\begin{array}{llllllllllllllllllll}F & E & C & S & Q & F & K & P & E & E & I & S & V & K & T & M & D & N & R & L\end{array}$ ATTTGAATGTAGCCAGTTTAAACCGGAAGAAATTAGCGTGAAAACCATGGACAATCGTCT $\begin{array}{llllllllllllllllllll}\text { C } & V & H & A & K & H & V & E & E & S & P & G & R & K & V & Y & R & E & F & T\end{array}$ CTGTGTTCACGCAAAACACGTCGAAGAATCTCCAGGCAGAAAAGTTTATCGGGAATTTAC $\begin{array}{llllllllllllllllllll}K & E & Y & T & L & P & K & N & V & D & P & L & R & L & T & S & T & L & S & K\end{array}$ AAAAGAATACACCCTGCCAAAGAATGTTGACCCTCTTCGCCTGACGTCCACTTTGTCCAA

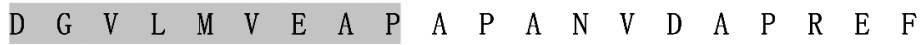
GGATGGCGTTCTGATGGTCGAAGCCCCTGCACCCGCCAACGTAGATGCTCCGAGAGAATT $\begin{array}{llllllll}\mathrm{L} & \mathrm{I} & \mathrm{P} & \mathrm{I} & \mathrm{E} & \mathrm{K} & \mathrm{M} & *\end{array}$ CTTAATTCCAATAGAAAAAATG TAAACAATAATAAGACATGGAGTCTCATCACGTGACAA TTTACATTTTAAAGTGTGCTTAAGATTGCTCTGATCTGTTATGAGAAGAAAAGAAAATAT TTATAAATGCGCATTCCAACTCATTACTGTTAAGGTTATTTGAATATCTTTGTTTCAAGA CGTTTTGCAATTTTTTGTAACTATTTCTACTTATTTAGCTTATCTATTAAATTGTTCAAT TCGGTTTTGTTCTGTTACAGTTGTGGTGAAGAAAAAACTTACGAACCCTAGCGTCATCTT GTATTACAACCATGAAAAACGTATACCAATTTTTTAATGAAATTCTTATTTTACGTCATG TTTTAGAGGGAAAATATCGTAAGTTTTCTGTTACATATCAAACTTTATTTGAAATATTTT GATTTTCGGAGGTACTATTTTCATCAAAATTACTTGCATCCACGTATATGTAAAAGAAGT ATCAACTTTTAATTTATCTGTATTTTTATGTTGGAGACGTATTCTTACATAATATGTTTC ATACTTTTTTCAAAATGAAATGAGATTTTATTAAAATTGTTTTATTAAACAAAAAAAAAA

Fig. 1. Meretrix meretrix. Nucleotide and predicted amino acid sequences of the novel small HSP gene Mm-HSP20. The start codon (ATG) and stop codon (TAA) are boxed. The amino acids that constitute the typical $\alpha$-crystallin domain are shaded

\section{Tissue-specific expression of Mm-HSP20 mRNA in healthy clams}

To examine the tissue distribution profile of MmHSP20, total RNA was isolated from hemocytes, gill, digestive gland, mantle, adductor muscle, and gonad tissues from 5 healthy clams. The Mm-HSP20 transcript was broadly expressed in all tissues tested.
Expression level was highest in the digestive gland, gill, and mantle tissues, and to a lesser degree in hemocytes, gonad, and adductor muscle (Fig. 4).

Because the digestive gland is a vital detoxification organ in most species, the relatively high expression level of $\mathrm{Mm}$ HSP20 tanscripts in the digestive gland of Meretrix meretrix suggests that it might be involved in the detoxification pathway. In mollusks, the digestive gland is also an important immune organ which can secrete many different enzymes to hydrolyze microorganisms and is involved in digestive and defense functions (Tiscar \& Mosca 2004). The high expression level of Mm-HSP20 in the digestive gland was consistent with the sHSP expression profile in Chlamys farreri (Zhang et al. 2010b). The gill, which is constructed of only a single layer of fragile cells and covered with a thin layer of protective mucus, has extensive contact with the environment. The high level of Mm-HSP20 transcript in the gill indicates that Mm-HSP20 contributes significantly to the mediation of environmental stress responses. MmHSP20 transcript is expressed in hemocytes, which indicates that mollusk hemocytes play an important role in many innate immune functions (Wootton et al. 2003, Li et al. 2012).

\section{Effects of short-term Cd and B[a]P exposure on Mm-HSP20}

Temporal Mm-HSP20 expression profiles in the digestive gland and hemocytes after $\mathrm{Cd}$ and $\mathrm{B}[\mathrm{a}] \mathrm{P}$ exposure were investigated using RT-PCR (Fig. 5). In the digestive gland, during the first $24 \mathrm{~h}$ after exposure to both $\mathrm{Cd}$ and $\mathrm{B}[\mathrm{a}] \mathrm{P}$, the Mm-HSP20 mRNA level remained low. Interestingly, the $\mathrm{B}[\mathrm{a}] \mathrm{P}$ challenge significantly decreased Mm-HSP20 mRNA expression levels $(p<0.05)$. At $48 \mathrm{~h}$ after Cd exposure, the Mm-HSP20 mRNA level was significantly up-regulated $(\mathrm{p}<0.01)$, reaching a peak 2.6-fold over the control. However, after B[a]P exposure, the Mm-HSP20 mRNA level had increased at $48 \mathrm{~h}$, but not to a statistically significant extent $(\mathrm{p}>$ 0.05). At $96 \mathrm{~h}$ after $\mathrm{Cd}$ exposure, the expression of Mm-HSP20 transcript returned to the baseline level. 


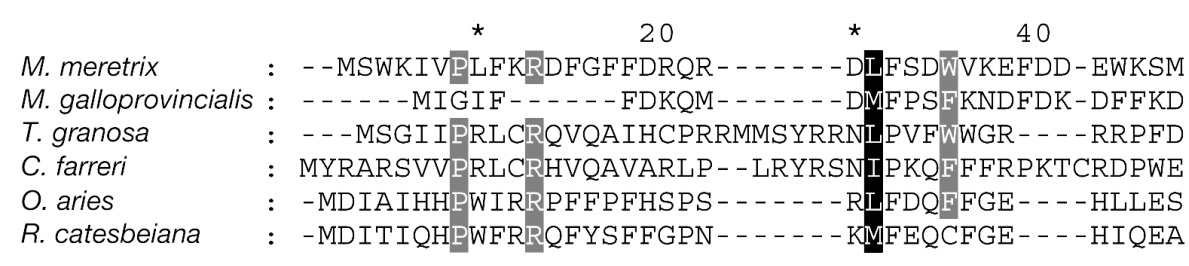

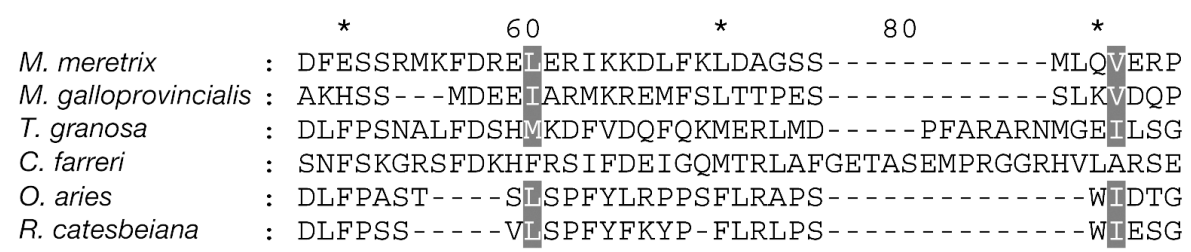

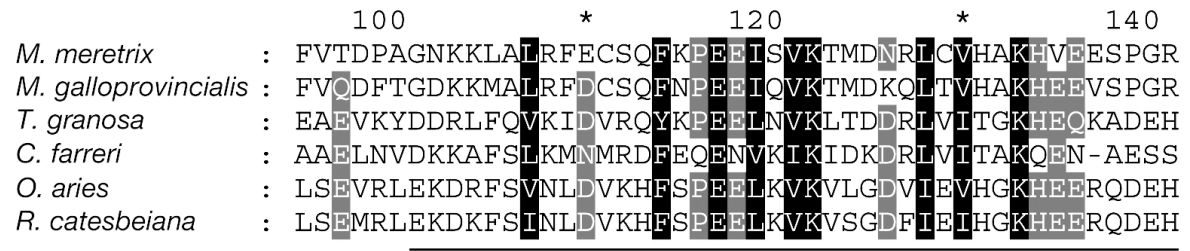

alpha-crystallin domain $(A C D)$
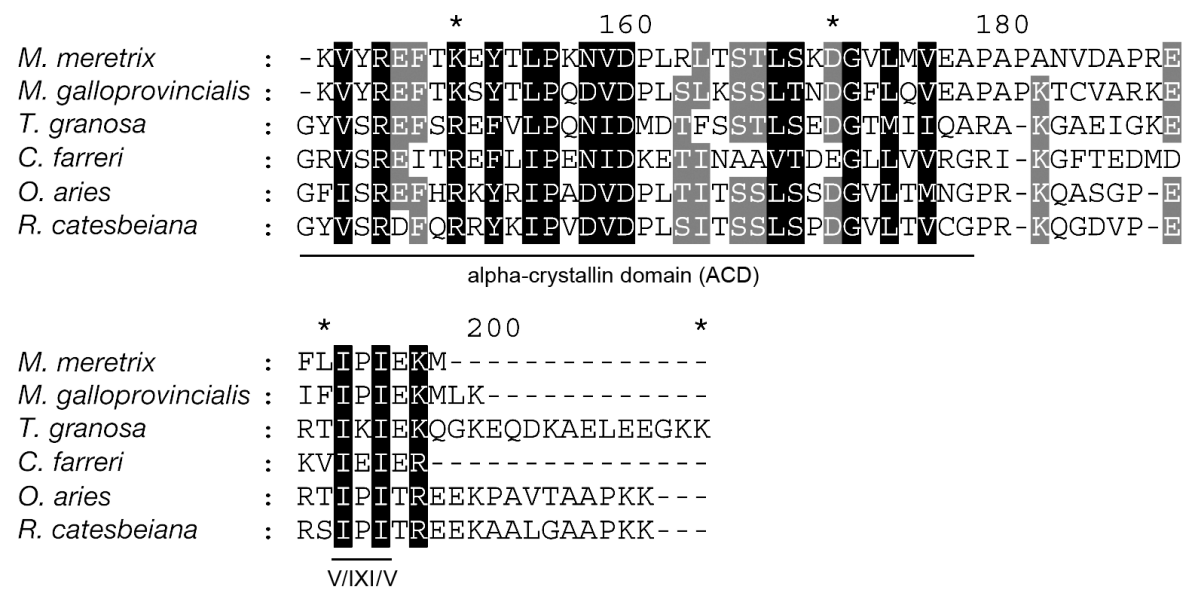

Fig. 2. Meretrix meretrix. Multiple sequence alignment of Mm-HSP20 with other small heat shock proteins (sHSPs). The conserved amino acid residues are shaded black, and similar amino acids are shaded in grey. The common feature sequence and motif are underlined and labeled. The species and Genbank accession numbers are as follows: Meretrix meretrix (JQ734546), Mytilus galloprovincialis (AEP02967), Tegillarca granosa (ADK94118), Chlamys farreri (AAR11780), Ovis aries (NP_001012475), and Rana catesbeiana (Q91312)

At $96 \mathrm{~h}$ after $\mathrm{B}[\mathrm{a}] \mathrm{P}$ exposure, the Mm-HSP20 mRNA level increased to 2.3-fold that of the controls ( $p<$ 0.01 ) (Fig. 5A). In hemocytes, the expression level of Mm-HSP20 mRNA was up-regulated gradually during the first $48 \mathrm{~h}$ post-B[a]P exposure. However, after $\mathrm{Cd}$ exposure, the Mm-HSP20 mRNA level in hemocytes had increased 1.7-fold at $48 \mathrm{~h}(\mathrm{p}<0.01)$ and 1.5 fold at $96 \mathrm{~h}(\mathrm{p}<0.05)$. After B[a]P exposure, the MmHSP20 mRNA level had increased 1.7 -fold ( $p<0.01$ ) at $48 \mathrm{~h}$ and 2.4 -fold at $96 \mathrm{~h}(\mathrm{p}<0.01)$ (Fig. 5B).

HSPs have become a valuable tool in investigations of marine pollutants because they are induced by many different contaminants. Previous studies have concentrated on the development of early warning biomarkers of pollution exposure (de Pomerai 1996). Some papers have reported a positive relationship between heavy metal stress and HSP mRNA expression level. In Zhikong scallop, CfHSP90 responds to various heavy metals $\left(\mathrm{Cd}^{2+}, \mathrm{Cu}^{2+}, \mathrm{Pb}^{2+}\right)$ in a dosedependent manner (Gao et al. 2007). A clearly dosedependent expression pattern of HSP22 in the bay scallop was also observed by Zhang et al. (2010a). In the present study, the Mm-HSP20 mRNA expression level in the digestive gland and hemocytes was sig- 


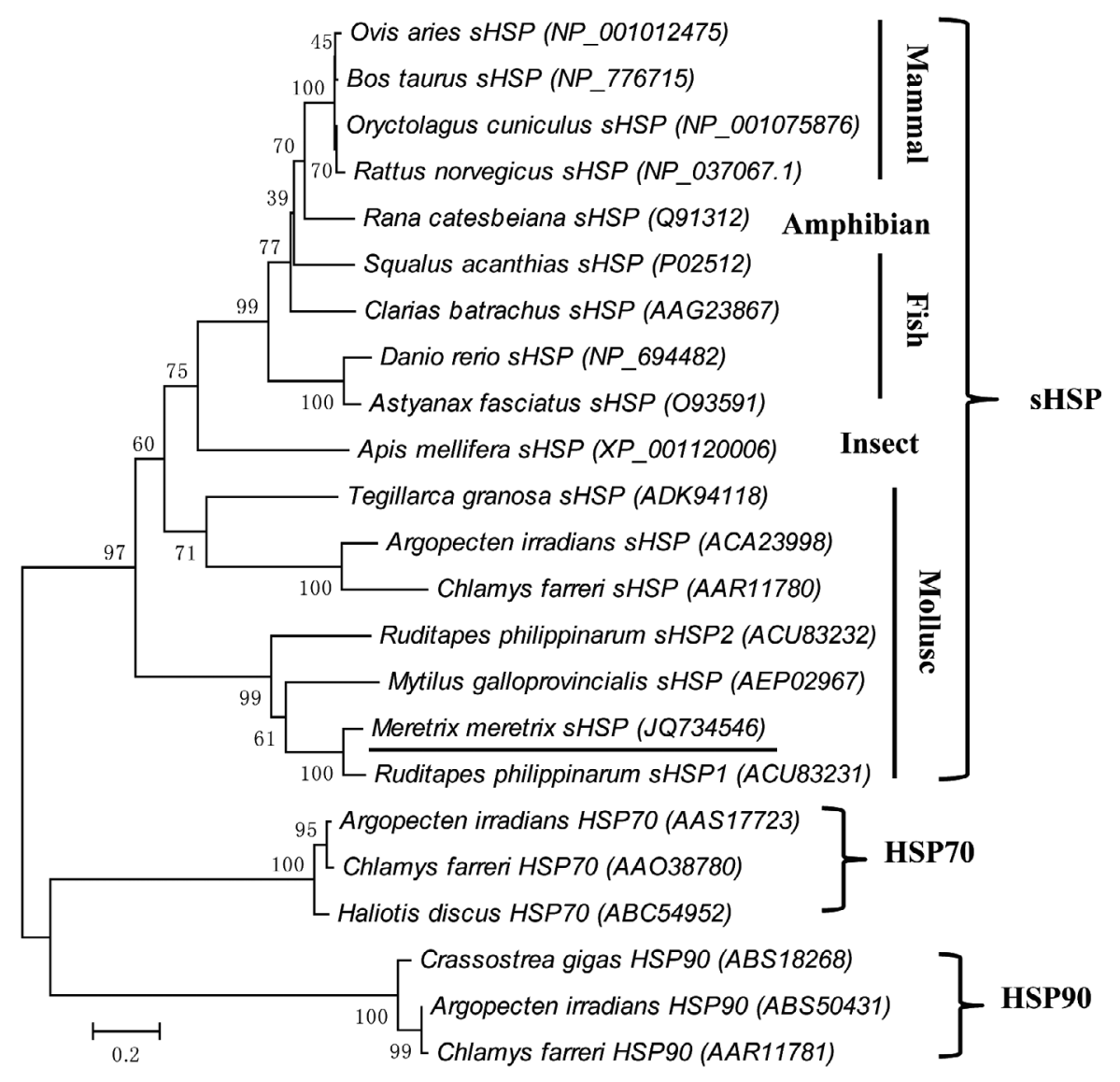

Fig. 3. Meretrix meretrix. Consensus neighbor-joining tree based on the amino acid sequences of various species' heat shock protein (HSP). The numbers at the forks indicate bootstrap values

nificantly up-regulated after Cd exposure. This result indicates that Mm-HSP20 plays a defensive role in heavy metal detoxification and protects against oxidative stress induced by $\mathrm{Cd}$ exposure. Similarly, many previous studies have showed that the expression of sHSPs at transcriptional level is increased in response to $\mathrm{Cd}^{2+}$ stress. Li et al. (2010) reported that 2 sHSPs from Ruditapes philippinarum, VpsHSP-1 and VpsHSP-2, responded differently to Cd exposure. Here, both genes were up-regulated with significant changes in response to low chemical exposure groups. The impact of temperature and $\mathrm{Cd}^{2+}$ stress on LcHSP27 expression was tested in the liver and brain tissues of the large yellow croaker Larimichthys crocea, which showed that the LcHSP27 expression level increased significantly after lowtemperature $\left(19^{\circ} \mathrm{C}\right)$ and high-temperature $\left(27^{\circ} \mathrm{C}\right.$ and $31^{\circ} \mathrm{C}$ ) stress. Moreover, low-temperature stress induced higher LcHSP27 expression in the liver than in the brain (Yang et al. 2012). These results were produced when $\mathrm{Cd}$ acted as a toxic stressor, and expres-

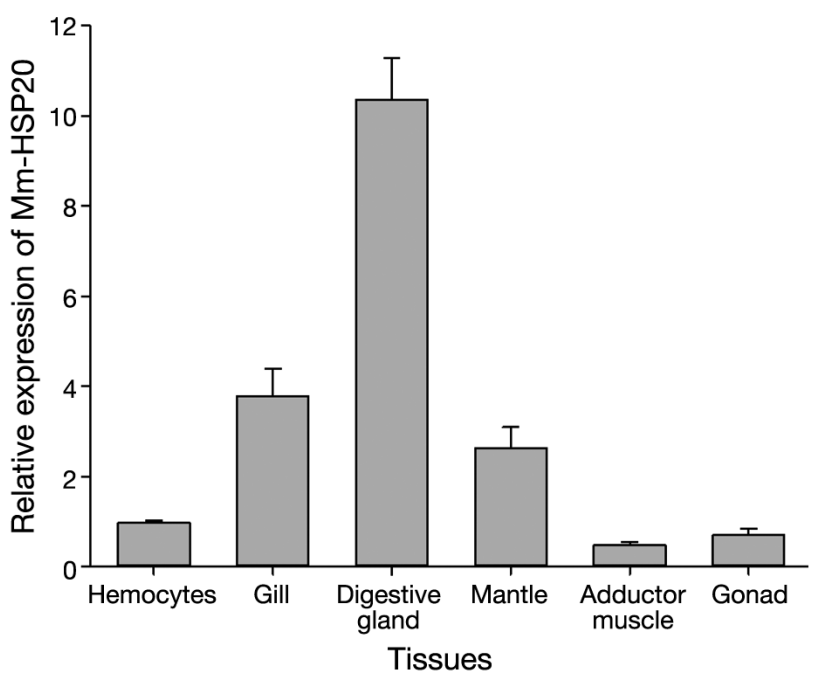

Fig. 4. Meretrix meretrix. Tissue expression of Mm-HSP20 mRNA in adult clams detected using real-time PCR. The relative expression values were determined by comparing the expression level of Mm-HSP20 to that of $\beta$-actin. Data are mean $\pm \mathrm{SD} ; \mathrm{n}=5$ 


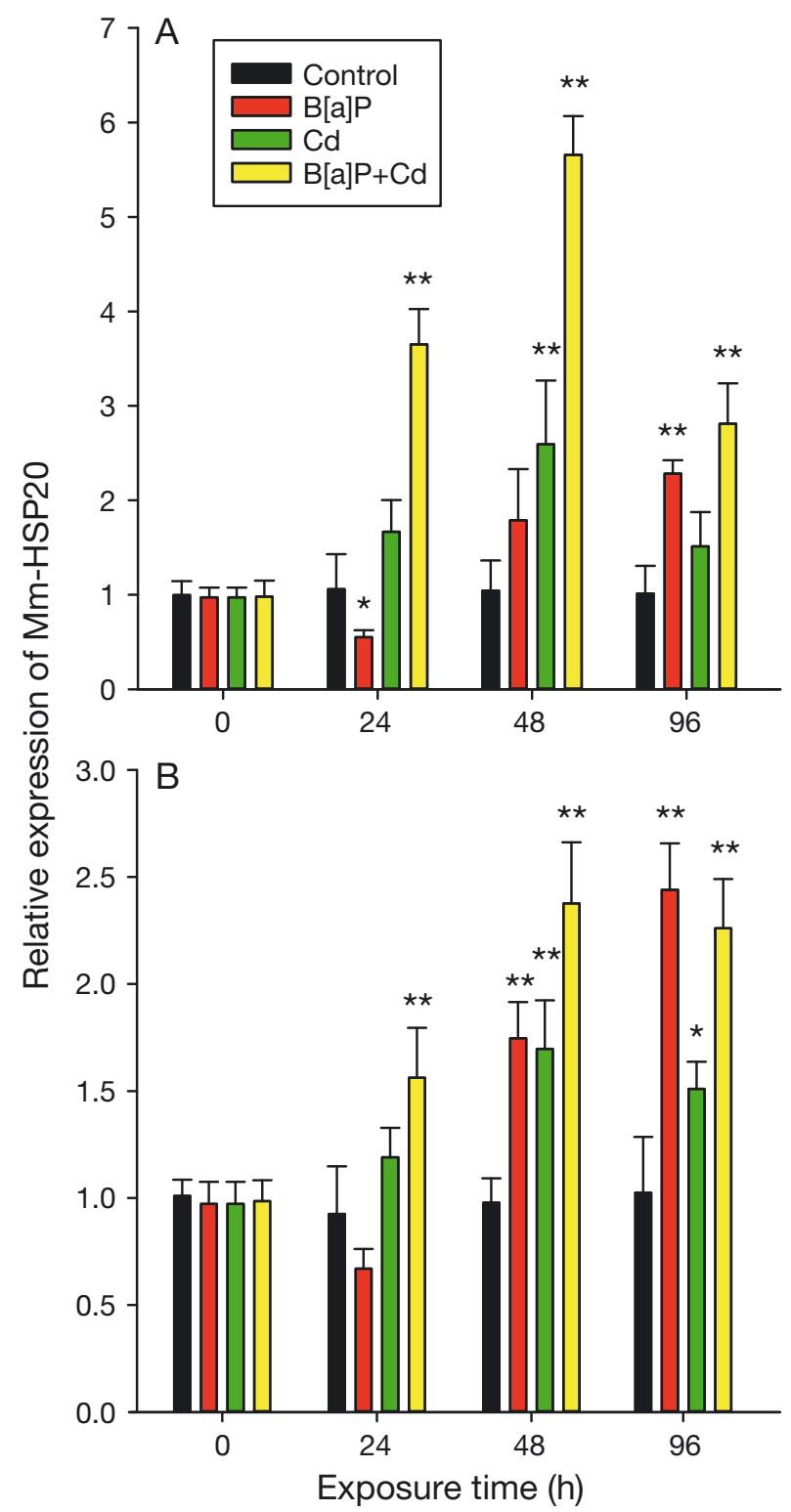

Fig. 5. Meretrix meretrix. Temporal expression of MmHSP20 mRNA. Expression profile in (A) the digestive gland and (B) hemocytes of clams exposed to benzo[a]pyrene (B[a]P; $\left.50 \mu \mathrm{g} \mathrm{l}^{-1}\right)$, cadmium $\left(\mathrm{Cd} ; 0 \mu \mathrm{g} \mathrm{l}^{-1}\right)$, and B[a]P (50 $\mu \mathrm{g}$ $\left.\mathrm{l}^{-1}\right)+\mathrm{Cd}\left(40 \mu \mathrm{g} \mathrm{l}^{-1}\right)$ for $0,24,48$, or $96 \mathrm{~h}$. Each bar represents a mean $( \pm \mathrm{SD} ; \mathrm{n}=4)$. Significant differences from control at the same sampling time: ${ }^{*} \mathrm{p}<0.05$ and ${ }^{* *} \mathrm{p}<0.01$

sion of sHSPs was induced to maintain homeostasis and to protect cells.

$\mathrm{B}[\mathrm{a}] \mathrm{P}$ has been shown to change the expression levels of HSP transcripts in the liver of medaka Oryzias javanicus fish (Won et al. 2011). In this study, the expression level of Mm-HSP20 mRNA was significantly up-regulated in response to $\mathrm{B}[\mathrm{a}] \mathrm{P}$ in the digestive gland and hemocytes. HSPs act as molecu- lar chaperones and therefore perform a critical role in coping with protein denaturation by environmental stresses. B[a]P may induce intracellular redox stress conditions, which trigger molecular chaperone immune defense functions (Xin et al. 2012). However, the expression level of Mm-HSP20 was down-regulated in the digestive gland at $24 \mathrm{~h}$ after $\mathrm{B}[\mathrm{a}] \mathrm{P}$ challenge. A similar expression pattern was also observed in the hemocytes of the bloody clam after Vibrio parahaemolyticus and LPS challenge (Bao et al. 2011). Recently, sHSPs have been found to block apoptosis (Oshita et al. 2010). A decrease in Mm-HSP20 mRNA was shown to be consistent with its negative regulator role in apoptosis ( $\mathrm{Li}$ et al. 2010).

\section{Effects of combined Cd and B[a]P exposure on Mm-HSP20}

Expression profiles of Mm-HSP20 in the digestive gland and hemocytes after exposure to $\mathrm{Cd}$ and $\mathrm{B}[\mathrm{a}] \mathrm{P}$ mixtures are shown in Fig. 5. Combined exposure induced a pronounced Mm-HSP20 mRNA level increase in both tissues, suggesting that exposure to multiple stressors has a synergistic effect. The level of Mm-HSP20 transcript increased significantly at $24 \mathrm{~h}$, reaching its highest level at $48 \mathrm{~h}$ after combined exposure, with a 5.7 -fold increase in the digestive gland and a 2.4 -fold increase in hemocytes. Evidence from other studies also indicates that HSPs show significant immune response to multiple stressors. In the large yellow croaker, LcHSP27 mRNA expression level shows dramatic up-regulation after the combined stress of temperature and cadmium (Yang et al. 2012). Our findings highlight the importance of considering multiple contaminants, such as heavy metal and $\mathrm{B}[\mathrm{a}] \mathrm{P}$, in the ecological risk assessment of a marine environment and also highlight the need for more research regarding the toxic effects of combined stressors on marine organisms.

\section{CONCLUSIONS}

In summary, a novel HSP20 gene of the hard clam Meretrix meretrix was identified and characterized as a member of the sHSP family. The Mm-HSP20 transcript was predominantly expressed in the digestive gland. Mm-HSP20 expression profiles produced after heavy metal or $\mathrm{B}[\mathrm{a}] \mathrm{P}$ exposure indicated its potential for use as a hard clam biomarker in monitoring marine environments. 
Acknowledgements. This work was supported by the National Natural Science Foundation of China (No. 31101899), a grant from the Zhejiang Key Laboratory of Exploitation and Preservation of Coastal Bio-resource (J2012001), open funding from the Key Laboratory of Fishery Ecology and Environment, Guangdong Province (GDKFL2012-06), the National Marine Public Welfare Research Project (200805080, 200805069, and 201305043), and the Leading Academic Discipline Project of Shanghai Municipal Education Commission (J50701).

\section{LITERATURE CITED}

Banni M, Negri A, Dagnino A, Jebali J, Ameur S, Boussetta H (2010) Acute effects of benzo[a]pyrene on digestive gland enzymatic biomarkers and DNA damage on mussel $M y$ tilus galloprovincialis. Ecotoxicol Environ Saf 73:842-848

Bao Y, Wang Q, Liu HM, Lin ZH (2011) A small HSP gene of bloody clam (Tegillarca granosa) involved in the immune response against Vibrio parahaemolyticus and lipopolysaccharide. Fish Shellfish Immunol 30:729-733

> Binelli A, Riva C, Cogni D, Provini A (2008) Assessment of the genotoxic potential of benzo(a)pyrene and $p p^{\prime}$ dichlorodiphenyldichloroethylene in zebra mussel (Dreissena polymorpha). Mutat Res 649:135-145

> Boening DW (1999) An evaluation of bivalves as biomonitors of heavy metals pollution in marine waters. Environ Monit Assess 55:459-470

Boonyatumanond R, Wattayakorn G, Togo A, Takada H (2006) Distribution and origins of polycyclic aromatic hydrocarbons (PAHs) in riverine, estuarine, and marine sediments in Thailand. Mar Pollut Bull 52:942-956

Cheng G, Basha E, Wysocki VH, Vierling E (2008) Insights into small heat shock protein and substrate structure during chaperone action derived from hydrogen/deuterium exchange and mass spectrometry. J Biol Chem 283: 26634-26642

de Pomerai D (1996) Heat-shock proteins as biomarkers of pollution. Hum Exp Toxicol 15:279-285

> Feder ME, Hofmann GE (1999) Heat-shock proteins, molecular chaperones, and the stress response: evolutionary and ecological physiology. Annu Rev Physiol 61:243-282

Franck E, Madsen O, van Rheede T, Ricard G, Huynen MA, de Jong WW (2004) Evolutionary diversity of vertebrate small heat shock proteins. J Mol Evol 59:792-805

Gao Q, Song L, Ni D, Wu L, Zhang H, Chang Y (2007) cDNA cloning and mRNA expression of heat shock protein 90 gene in the haemocytes of Zhikong scallop Chlamys farreri. Comp Biochem Physiol B 147:704-715

> Hartl FU (1996) Molecular chaperones in cellular protein folding. Nature 381:571-579

$>$ Hu NJ, Shi XF, Liu JH, Huang P, Liu YG, Liu Y (2010) Concentrations and possible sources of PAHs in sediments from Bohai Bay and adjacent shelf. Environ Earth Sci 60: 1771-1782

Li CH, Wang LL, Ning XX, Chen AQ and others (2010) Identification of two small heat shock proteins with different response profile to cadmium and pathogen stresses in Venerupis philippinarum. Cell Stress Chaperones 15: 897-904

Li HJ, Zhu D, Gao XG, Li YF, Wang J, He CB (2009) Mining single nucleotide polymorphisms from EST data of hard clam Meretrix meretrix. Conserv Genet Resour 2:69-72 Li HJ, Liu WD, Gao XG, Zhu D, Wang J, Li YF, He CB (2011)
Identification of host-defense genes and development of microsatellite markers from ESTs of hard clam Meretrix meretrix. Mol Biol Rep 38:769-775

Li HJ, Yang Q, Gao XG, Su H, Wang J, He CB (2012) Identification and expression of a putative LPS-induced TNF- $\alpha$ factor from Asiatic hard clam Meretrix meretrix. Mol Biol Rep 39:865-871

Lindquist S, Craig EA (1988) The heat-shock proteins. Annu Rev Genet 22:631-677

> Livak KJ, Schmittgen TD (2001) Analysis of relative gene expression data using realtime quantitative PCR and the $2^{-\Delta \Delta \mathrm{CT}}$ method. Methods 25:402-408

> Lowe DM, Moore MN, Readman JW (2006) Pathological reactions and recovery of hepatopancreatic digestive cells from the marine snail Littorina littorea following exposure to a polycyclic aromatic hydrocarbon. Mar Environ Res 61:457-470

> Men B, He MC, Tan L, Lin CY, Quan XC (2009) Distributions of polycyclic aromatic hydrocarbons in the Daliao River Estuary of Liaodong Bay, Bohai Sea (China). Mar Pollut Bull 58:818-826

> Meng W, Qin YW, Zheng BH, Zhang L (2008) Heavy metal pollution in Tianjin Bohai Bay, China. J Environ Sci 20: 814-819

- Morimoto RI (1993) Cells in stress: transcriptional activation of heat shock genes. Science 259:1409-1410

> Narberhaus F (2002) $\alpha$-Crystallin-type heat shock proteins: socializing minichaperones in the context of a multichaperone network. Microbiol Mol Biol Rev 66:64-93

Oshita SE, Chen F, Kwan T, Yehiely F, Cryns VL (2010) The small heat shock protein HspB2 is a novel anti-apoptotic protein that inhibits apical caspase activation in the extrinsic apoptotic pathway. Breast Cancer Res Treat 124: 307-315

> Pan K, Wang WX (2012) Trace metal contamination in estuarine and coastal environments in China. Sci Total Environ 421-422:3-16

> Parsell DA, Lindquist S (1993) The function of heat-shock proteins in stress tolerance: degradation and reactivation of damaged proteins. Annu Rev Genet 27:437-496

> Pasta SY, Raman B, Ramakrishna T, Rao CM (2004) The IXI/V motif in the C-terminal extension of alpha-crystallins: alternative interactions and oligomeric assemblies. Mol Vis 10:655-662

> Rainbow PS (1995) Biomonitoring of heavy metal availability in the marine environment. Mar Pollut Bull 31:183-192

Reynaud S, Deschaux P (2006) The effects of polycyclic aromatic hydrocarbons on the immune system of fish: a review. Aquat Toxicol 77:229-238

> Soclo HH, Garrigues P, Ewald M (2000) Origin of polycyclic aromatic hydrocarbons (PAHs) in coastal marine sediments: case studies in Cotonou (Benin) and Aquitaine (France) areas. Mar Pollut Bull 40:387-396

Sun Y, MacRae TH (2005) Small heat shock proteins: molecular structure and chaperone function. Cell Mol Life Sci 62:2460-2476

Tamura K, Dudley J, Nei M, Kumar S (2007) MEGA4: molecular evolutionary genetics analysis (MEGA) software version 4.0. Mol Biol Evol 24:1596-1599

> Tiscar PG, Mosca F (2004) Defense mechanisms in farmed marine molluscs. Vet Res Commun 28(Suppl 1):57-62

Wan L, Wang NB, Li QB, Sun B and others (2008) Distribution of dissolved metals in seawater of Jinzhou Bay, China. Environ Toxicol Chem 27:43-48

> Wang L, Pan LQ, Liu N, Liu D, Xu CQ, Miao JJ (2011) 
Biomarkers and bioaccumulation of clam Ruditapes philippinarum in response to combined cadmium and benzo[a]pyrene exposure. Food Chem Toxicol 49:3407-3417

Wang Q, Liu BZ, Yang HS, Wang XY, Lin ZH (2009) Toxicity of lead, cadmium and mercury on embryogenesis, survival, growth and metamorphosis of Meretrix meretrix larvae. Ecotoxicology 18:829-837

> Wang Q, Wang X, Wang X, Yang H, Liu B (2010) Analysis of metallotionein expression and antioxidant enzyme activities in Meretrix meretrix larvae under sublethal cadmium exposure. Aquat Toxicol 100:321-328

> Wang WX (2002) Interactions of trace metals and different marine food chains. Mar Ecol Prog Ser 243:295-309

Won H, Yum S, Woo S (2011) Identification of differentially expressed genes in liver of marine medaka fish exposed to benzo[a]pyrene. Toxicol Environ Health Sci 3:39-45

- Wootton EC, Dyrynda EA, Ratclie NA (2003) Bivalve immunity: comparisons between the marine mussel (Mytilus edulis), the edible cockle (Cerastoderma edule) and the razor-shell (Ensis siliqua). Fish Shellfish Immunol 15: 195-210

> Xin L, Li XH, Deng HX, Kuang D and others (2012) Development of stable HSPA1A promoter-driven luciferase reporter HepG2 cells for assessing the toxicity of organic pollutants present in air. Cell Stress Chaperones 17: 567-576

> Xu B, Yang XB, Gu ZY, Zhang YH, Chen YF, Lv YW (2009) The trend and extent of heavy metal accumulation over last one hundred years in the Liaodong Bay, China.

Editorial responsibility: Christine Paetzold,

Oldendorf/Luhe, Germany
Chemosphere 75:442-446

> Yang QL, Yao CL, Wang ZY (2012) Acute temperature and cadmium stress response characterization of small heat shock protein 27 in large yellow croaker, Larimichthys crocea. Comp Biochem Physiol C Toxicol Pharmacol 155: 190-197

> Yuan CG, Shi JB, He B, Liu JF, Liang LN, Jiang GB (2004) Speciation of heavy metals in marine sediments from the East China Sea by ICP-MS with sequential extraction. Environ Int 30:769-783

Yue X, Liu BZ, Xiang JH, Jia JT (2010) Identification and characterization of the pathogenic effect of a Vibrio parahaemolyticus-related bacterium isolated from clam Meretrix meretrix with mass mortality. J Invertebr Pathol 103:109-115

Zhang G, Fang XD, Guo XM, Li L and others (2012) The oyster genome reveals stress adaptation and complexity of shell formation. Nature 490:49-54

Zhang L, Wang LL, Song LS, Zhao JM and others (2010a) The involvement of HSP22 from bay scallop Argopecten irradians in response to heavy metal stress. Mol Biol Rep 37:1763-1771

> Zhang L, Wang LL, Zhao JM, Qiu LM, Song LS, Dong CH, Li FM (2010b) The responsive expression of heat shock protein 22 gene in Zhikong scallop Chlamys farreri against a bacterial challenge. Aquac Res 41:257-266

Zhang ZH, Zhu MY, Wang ZL, Wang J (2006) Monitoring and managing pollution load in Bohai Sea, PR China. Ocean Coast Manage 49:706-716

Submitted: August 13, 2012; Accepted: February 18, 2013 Proofs received from author(s): May 25, 2013 